Jurnal The Messenger, Vol. 12, No. 1, January 2020, pp. 63-73

P-ISSN: 2086-1559, E-ISSN: 2527-2810

DOI: $10.26623 /$ themessenger.v12i1.1814

\title{
Content Analysis of HPV Vaccine Messages on Chinese Social Media
}

\section{Analisis Isi Pesan-pesan tentang Vaksin HPV dalam Media Sosial di Republik Rakyat Tiongkok}

\author{
Xianglin $\mathrm{Su}^{1}$ \\ ${ }^{1}$ College of Communication, Shenzhen University, 3688 Yuehai Street, Nanshan \\ District, Shenzhen 51800, Guangdong, China \\ *Corresponding author, e-mail: 2170094510@email.szu.edu.cn
}

\begin{abstract}
The present study aimed to explore the characteristics and effects of messages about the Human Papillomavirus (HPV) vaccine on WeChat, a social media platform in China, with the theoretical underpinning of the Limited Capacity Model of Motivated Mediated Message Processing and the Health Belief Model. Researcher carried on content analysis and found that severity (37.82\%), susceptibility (36.13\%), benefits (68.07\%), and barriers (47.9\%) have appeared in WeChat. The target audience was mainly women (91.5\%), and most of the media platforms were non-medical organizations (72.27\%). People in China had a positive attitude toward HPV9. The research findings elucidated to explore the effectiveness of the messages about the HPV vaccine on WeChat, indicated that the potential effects of social media messages on individual cervical cancer prevention intentions and behaviors. In the end, researcher proposed some strategies for identifying the messages, and the implications of the findings were also discussed.
\end{abstract}

Keywords: Cervical Cancer, HPV9, Social Media Platform, WeChat, China.

\begin{abstract}
Abstrak
Penelitian ini bertujuan untuk mengeksplorasi karakteristik dan efektifitas pesan tentang vaksin Human Papillomavirus (HPV) di WeChat, sebuah platform media sosial di Republik Rakyat Tiongkok (RRT), dengan landasan teoritis Model Kapasitas Terbatas dari Pemrosesan Pesan yang Dimediasi dengan Motivasi, dan Model Kepercayaan Kesehatan. Peneliti melakukan analisis isi dan menemukan bahwa tingkat keparahan (37.82\%), kerentanan (36.13\%), manfaat (68.07\%) dan hambatan (47.9\%) telah muncul di WeChat. Target audiens utamanya adalah perempuan (91.5\%), dan sebagian besar platform media adalah organisasi non-medis $(72.27 \%)$. Orang-orang di RRT memiliki sikap positif terhadap HPV9. Temuan penelitian dijelaskan untuk mengeksplorasi efektivitas pesan tentang vaksin HPV di WeChat, menunjukkan bahwa efek potensial dari pesan-pesan media sosial pada niat dan perilaku pencegahan kanker serviks individu. Pada akhirnya, peneliti mengusulkan beberapa strategi untuk mengidentifikasi pesan, dan implikasi temuan juga dibahas.
\end{abstract}

Kata Kunci: Kanker Serviks, HPV9, Platform Media Sosial, WeChat, RRT.

\section{Introduction}

Studies showed that the production and dissemination of content related to health information affect people's perceptions and behaviors (Dewi \& Anisa, 2018). Health communication has become an essential part of communication studies, emphasized the effectiveness and accuracy of media health information transmission, and gradually eliminated the obscurity caused by lack of knowledge and obsolescence, to build a scientific and sound health knowledge system and social health picture. Especially cervical cancer is the second most common female cancer in the world. It is estimated

Article History: Received December 24, 2019; Revised January 12, 2020; Accepted January 26, 2020; Published January 31, 2020 
that there are up to 500.000 newly diagnosed cases of cervical cancer worldwide and more than 268.000 cases of death each year. According to the World Health Organization, about 75.000 of the world's new cases of cervical cancer are from China (Li et al., 2013). It had received more attention in China. Therefore, from the perspective of medical health, new screen and active examination are essential for the prevention and treatment of cervical cancer. In recent years, a large number of advanced prevention technologies have been accelerated into clinical applications. With the gradual list of the Human Papillomavirus (HPV) vaccines in China, the female public has more reliable prevention options.

Social media related health information was increasingly integrated into the daily life of Chinese people. Especially the WeChat, a social media platform just like Facebook in China, with 1.01 billion users logging it every day. WeChat has formed a new and vast social network, created an ecosystem of social, media, commercial office, and payment that attracted more and more researchers. WeChat official account was launched in August 2012, including the service and subscription account, where the service account is only applied for registration by the enterprise or organization. Any organization or individual can apply for the public account's subscription and perform graphic, voice, and video information through background management and then send it to the person who subscribed.

Although the quality of the information is mixed, it is undeniable that the large subscription account has become an important source to get the HPV vaccine message. Moreover, WeChat is also a network platform for Chinese people to get knowledge of health-related messages (Shi \& Salmon, 2018). The HPV vaccine messages on the WeChat were produced by self-media accounts, which includes hospital, doctor, or local news media, etcetera, addressed to their fan who subscribed or cared for the ill.

The present study aimed to explore the characteristics and effects of messages about the HPV vaccine on the WeChat official account, with the theoretical underpinning of the Limited Capacity Model of Motivated Mediated Message Processing (LC4MP) and the Health Belief Model (HPB). LC4MP, which addresses that the processing of the message involves encoding, storage, and retrieval, and everybody has only a limited cognitive resource to grasp the message. Specifically what is the key point to design useful health communication messages. Moreover, HPB is trying to understand why individuals, whether engaging in a wide variety of health-related actions, illuminated that it depends on the value of people's goals and the likelihood of achieving their goals. We hope the content analysis can propose some strategies for identifying health messages.

\section{HPV Related-information on Social Media}

Although the related factors affecting people's choice of healthy behavior include many aspects, such as culture, economy, concept, habit, history, etcetera, the origin of these aspects still lies in the acquisition of information and long-term knowledge construction, and the media is the contact source between information and public (Mubarok, 2018). Moreover, one of the channels to gain knowledge. The scientific information content may cultivate the female public's correct cognition and positive prevention attitude towards cervical cancer. For the media, the production of knowledgebased information that meets the real needs of the public is of paramount importance in cultivating the public's health information consumption habits and further enhancing women's willingness to prevent high-risk diseases such as cervical cancer. Researchers have recently found that HPV related information on media as a source to get the knowledge of cervical cancer and shape the general public's belief (Watson et al., 2009).

Jurnal The Messenger, Vol. 12, No. 1, January 2020, pp. 63-73 
Such as private blog content can also affect public health beliefs.

However, it is easy to lead to the polarization of the audience's views on vaccine efficacy and safety (Nan \& Daily, 2015). Some studies found that as the number of women's health issues reported and coverage increased, the coverage of cervical cancer screening increased accordingly (Metcalfe et al., 2011). In terms of content, different types of information frameworks (gain framework or loss framework) and individual risk perception (high or low) have an interactive impact on the public's willingness to inoculate the HPV vaccine (Park, 2012). Some scholars have explored the influence of the weight change of 'sickness severity-disease cure rate' on the individual's perception of the threat of cervical cancer disease. The results showed that the best stimulating effect is when the information mentions that the severity and the relevant content of the disease can be cured (Carcioppolo et al., 2013). Some scholars have clearly stated that people's awareness of the severity of cervical cancer and their willingness to prevent it depends on the specific online information dissemination channels. The loss framework information published on social media (such as Facebook) is more likely to enhance individual prevention intentions than the gain framework. However, when the online newspaper showed the same message, there was no similar frame effect (Lee \& Cho, 2017). Nevertheless, the health message on social media was scarce, the unprecedented impact of social media on social and personal life may mean that HPV information in such media can help improve people's perceptions of health beliefs.

2. The Health Belief Model and related Health Information

As for how people's beliefs and attitudes toward health have changed, scholars have been enthusiastically explored it for a long time. Particularly the Health Belief Model remains one of the best known and most widely used theories in health behavior research (Carpenter, 2010). According to the Health Belief Model (Rosenstock, 2005), stated that which beliefs should be targeted in communication campaigns to cause positive health behaviors. Considered the behavior depends mainly upon two variables: (1) the value placed by an individual on a particular goal; and (2) the individual's estimate of the likelihood that a given action will achieve that goal. Conceptualized means that (1) the desire to avoid illness (or if ill, to get well); and (2) the belief that a specific health action will prevent (or ameliorate) illness (that is the individual's estimate of the threat of illness, and of the likelihood of being able, through personal action, to reduce that threat).

More specifies is that if individuals believe that adverse health outcomes are severe and that they are susceptible. At the same time, they will recognize that perceive the benefits of behavior will reduce the likelihood of such outcomes, and perceive the barriers to adopting those behaviors to below, then the behavior is likely for those individuals. Which can summarize to these variables: perceived susceptibility refers to one's subjective perception of the risk of contracting a condition, perceived severity feelings concerning the seriousness of contracting an illness, perceived benefits regarding the effectiveness of the various actions available in reducing the disease threat, on the contrary, perceived barriers mean that the potential negative aspects of a particular health action may act as impediments to undertaking the recommended behavior.

Some meta-analysis studies were conducted found what factors were the most important, influential, and longitudinally to predict an individual's health behavior change. Scholars deem think the perceived benefits and perceived barriers variables were the consistently the most influential predictors, the benefits effect size is 0.27 , the barriers effect size is 0.3, all of them almost are the common effects (Carpenter, 2010). Janz and Becker integrated nearly ten years of related literature, including Sick-Role Behaviors 
(SRB), Preventive-Health Behaviors (PHB) and HBM, showed that perceived barriers proved to be the most powerful of the HBM dimensions across the various study designs and behaviors, overall perceived susceptibility also was a more substantial contributor, perceived benefits and perceived severity produced the lowest overall significance ratios (Janz \& Becker, 1984). Why the perceived barriers can cause such a vast belief change and persuasion impact to individuals? Witte illuminated that fear appeal in EPPM is a persuasive message that attempts to trigger fear by portraying significant threats associated with the individual, and then suggests feasible and practical recommendations to prevent further development of the event, which hypothesized that the relationships among health consciousness, perceived severity, perceived susceptibility, perceived response efficacy, perceived self-efficacy, and message acceptance or rejection (Witte, 1992). Witte proposes two mental processes: danger control versus fear control involves two steps of appraisals.

First is the perceived threat or danger of the unhealthy condition in severity and susceptibility (audience's thoughts and perceptions of danger); second is the efficacy (practical approach to help the audience respond to threats). Hong researched the attitude of 175 viewers on the news reports of health information on TV was collected. The result showed that perceived severity, efficacy (response efficacy, and self-efficacy) were the influence of health consciousness on message acceptance (Hong, 2011). scholars generally believe that increasing the fear perception, threat intensity and high-efficacy measures in the information can optimize the persuasion effect (Rogers, 1985; Witte \& Allen, 2000). Some research revealed that a 1-to-1 ratio of the threat to efficacy was most effective at increasing the public's prevention intentions in HPV information (Carcioppolo et al., 2013). And we mainly aimed to address the characteristics of HPV information in social media by asking:

RQ1: How frequently do HPV messages on WeChat official accounts include susceptibility, severity, barriers, and benefits related-information?

3. The Limited Capacity Model of Motivated Mediated Message Processing and related Health Information

In addition to the characteristics of the information content itself that will affect people's health beliefs and attitudes, other researches showed that the platform of media information, the target group, and the purpose of publishing the information itself have different degrees of impact on it. The Limited Capacity Model of Motivated Mediated Message Processing model (LC4MP), was from the perspective of cognitive information processing of the human brain, which hypothesis that the human brain has limited cognitive resources to expend on the tasks of perceiving, encoding, understanding, and remembering (Lang, 2006). To deliver useful messages about health-related information and behaviors to people who would benefit from those messages, it is as possible to clarify the related-information to individuals. To ensure the vital part of a message encoded in the human brain, the LC4MP put forward four significant aspects, the goals of the message, the target audience, the medium of the message, the motivational and personal relevance information. According to Lang's rich experimental research experience, in general, the purpose of cancer information in health communication research is mainly divided into awareness (for example: of new findings), reinforcement of behaviors that decrease cancer risk (for example: not smoking), knowledge gain (creating messages that give people information about cancer, medication, treatment, etcetera). Furthermore, the main focus of health communication research is adolescents and women. The medium of

Jurnal The Messenger, Vol. 12, No. 1, January 2020, pp. 63-73 
the message, including the text, audio, and pictures, which plays an extremely different role. On the other aspect, the public has two motivational systems, one is appetitive (for good), another is the aversive system (for evil) (Bradley \& Lang, 1994). In response, we want to explore the characterizes of HPV related message on WeChat official accounts by asking:

RQ2: What is the goal of the HPV related message on WeChat official accounts?

RQ3: What kind of target audience is the information of HPV in WeChat official accounts?

RQ4: Who is the main publisher of HPV information in WeChat's official accounts and their attitudes to the HPV9?

\section{Method}

\section{Data Collection}

Much substantial empirical research has found that perceived barriers and perceived susceptibility of HPB are the essential variables to affect individuals engaging heath actions. According to several aspects of the theories, the goals of the message, the target market, the message medium, the motivational and personal relevance of the main health information which means that message person's primary concern including the barriers, susceptibility, benefits, and severity, we carried on content analysis.

Researcher used the following keywords, namely, 'Human Papillomavirus Vaccine (HPV9), Cervical Cancer Vaccine (Gardasil 9)' in the content of title, searched on the WeChat official account, the total data was 7795. Considering the vast information on social media, the first thing we did was to extract all the related-information with python web crawler in January 2019. However, WeChat's anti-reptile ability is too strong, and the network link that crawled out is short-lived, it will expire in an hour and need login information to get more data. So limited based on technical capabilities, researcher gave up the way to crawl related data with Python. Then researcher finally decided to get the relevant information manually. After the first round of search, researcher made a screening of these messages, removed all advertisements. Then researcher kept the related as the following selected criteria: (a) only text message, not video and graph; (b) exclude some message about other cancers; (c) messages with theoretical variables concerning the determinants of cervical cancer; and (d) removing the content about sharing the experience of injecting HPV9 vaccination. Then researcher recruited two coders to organize the related information, removed duplicate content, leaving 119 items, completed the code work between June and July 2019.

2. Coding Procedure

Then researcher made code categories in the context of HPV as the basis of analysis. Cause the motivational system has two different aspects (appetitive or aversive), so researcher decided to code the motivational and personal relevance as the people's attitude to the title, including the positive, neutral and negative. The medium of the message, all researcher code is text, so researcher defined it as the subject of publishing information, including non-medical organizations, non-pharmaceutical individuals, and medical organizations or individuals.

The following information was coded from each message: (1) message goals, including awareness (new treatments and findings of HPV), reinforcement of behaviors that decrease cancer risk (use the condom in sexual life), knowledge gain (symptomatic of cervical cancer, what cause the ill); (2) the target market (gender and age); (3) the message medium (according to the brief introduction information of WeChat official 
account as the judgment basis), including: (a) non-medical individuals, (b) non-medical organizations, (c) medical individuals or organizations; (4) barriers; (5) susceptibility; (6) benefits; (7) severity (see table 1). The four variables were coded as being present one or absent 0 , being category variables. To avoid the ambiguity in the coding process, and the coders often discussed some specific meaning in the context (Liu \& Wilson, 2011).

\begin{tabular}{|c|c|c|}
\hline Variable & Definition & Example \\
\hline Susceptibility & $\begin{array}{l}\text { The information } \\
\text { mentioned the } \\
\text { likelihood to get } \\
\text { cervical cancer }\end{array}$ & $\begin{array}{l}\text { Women are very susceptible to cervical cancer, } \\
\text { and it is widespread in women. }\end{array}$ \\
\hline Severity & $\begin{array}{l}\text { The information } \\
\text { mentioned the } \\
\text { seriousness of } \\
\text { cervical cancer }\end{array}$ & $\begin{array}{l}\text { Cervical cancer is a severe disease that can lead } \\
\text { to death, pain, etcetera, and has a bad influence } \\
\text { on social relationships such as family work. }\end{array}$ \\
\hline Benefits & $\begin{array}{l}\text { The benefits of } \\
\text { injection HPV } \\
\text { vaccine }\end{array}$ & $\begin{array}{l}\text { Injection of the HPV vaccine helps reduce the } \\
\text { perceived risk of illness. }\end{array}$ \\
\hline Barriers & $\begin{array}{l}\text { Difficulties in } \\
\text { injecting HPV } \\
\text { vaccine }\end{array}$ & $\begin{array}{l}\text { The cost of injecting HPV vaccines is expensive, } \\
\text { the existence of fake vaccines, hidden side } \\
\text { effects, pain, and difficulty in obtaining vaccines } \\
\text { (need to go to Hong Kong to make } \\
\text { appointments, rocking appointments, etcetera). }\end{array}$ \\
\hline
\end{tabular}

Table 1. Theoretical Variables Definitions in the Context of HPV

(source: author's analysis)

\section{Results and Discussion}

Reliability. Coded from 2019 January 1 to 31 about a month, eventually, two coders coded 119 samples. Calculated Krippendorff's alpha with the 'irr' package of R 3.5.1. The inter-coder reliability is 0.69 for barriers, 0.73 for susceptibility, 0.83 for severity, 0.77 for benefits, which indicated that the two coders have higher reliability.

In response to this research questions, researcher finally conducted a statistical analysis of 119 samples, and the result showed in the table 2 . Totally $37.82 \%$ messages presented the severity by clarifying that cause death or cancer, killer, and so on (for example, 'Studies showed that more than $70 \%$ of cervical cancers are associated with HPV, cause male or female anal, genital diseases and oropharyngeal diseases, cervical cancer is a common malignant tumor that seriously threatens women's health, famous movie star Mei Lan fang died of cervical cancer, in the past ten years, the incidence and mortality of cervical cancer in China have increased year by year, and it is much more younger. The incidence rate is the fifth in all malignant tumors in women and the second in gynecological malignancies, and according to the World Health Organization survey report, the incidence of gynecology in Chinese women is as high as $90 \%$. In addition to breast cancer, cervical cancer is the second biggest killer of women's health. According to the 2015 China Cancer Statistics Report, in China, one woman has cervical cancer every single 5 minutes, and one woman succumbs to cervical cancer by every 17 minutes').

In messages indicating the public's susceptibility $(36.13 \%)$ by stated that (for example, 'HPV is primarily transmitted through sexual contact, so every sexually active

Jurnal The Messenger, Vol. 12, No. 1, January 2020, pp. 63-73 
woman is at risk of contracting carcinogenic HPV, about 4 out of 5 people will be infected with at least one HPV after starting sex, more than $90 \%$ of cervical cancer is caused by HPV infection'), and $68.07 \%$ of messages related to benefits, for example, 'cervical cancer vaccine will significantly reduce the incidence of cervical cancer and its precancerous lesions, thereby reducing the burden of disease, nine-valent vaccine can prevent almost $92.1 \%$ of cervical cancer and more than $90 \%$ of genital warts.'

The proportion of barriers is $47.9 \%$, mentioned that the suitable of not for vaccination, such as 'allergic to eggs, yeast, fever, pregnancy' or the typical adverse reactions include: redness and swelling in the injection site of the arm, pain, a slight headache or feeling tired, nausea and vertigo have muscle or joint pain, even the cost is expensive, HPV9 resources are scarce and must be qualified for injection employing a lottery. Plus, it must be mentioned that the circulation of fake vaccines on the market is the most worrying to the public. In the coding process, there is eight information about fake vaccines in Hainan, China, and two about water vaccine events in Hong Kong. The above was the general content of RQ1.

From the data showed above, and researcher can know that the largest proportion was benefits message, the proportion of severity and susceptibility was similar equal. According the EPPM and HPB model, an effective fear-appeal message needs to indicate the severity of the threat as well as the audience's susceptibility to it. The WeChat platform first set some fear agenda for people, which could make the people feel some panic about their body health. Then they provide some cure tips to solve the problem. According the limited capacity model of motivated mediated message processing model (LC4MP) proposed by Lang, who thinks delivering a useful message about health-related information and behaviors to people, it is as possible to clarify the related-information to individuals, which means that suggest benefit messages for them. WeChat platform transferred more benefits message about HPV9 was a good choice to attract people's attention, and make a high level cognitive to behavior change. And there were some risks mentioned, when people conducted the behavioral changes maybe face some barriers, such as the cost expensive or rare cures. To conclude, the WeChat platform have a good attitude to the HPV9 vaccine, and made effective strategies to convey the health message for public.

As for RQ2, 94.95\% messages were awareness, which content was almost about the HPV vaccine itself, such as compared the difference between the HPV2, HPV4 and HPV9 in the types of viruses that can be prevented and the diseases caused, the people who is suitable to inject the vaccine, the probability of preventing and treating cervical cancer, and the time interval and the number of injections. According the LC4MP theory, the awareness messages make a clean clarify about the current satiation of cervical cancer, which can help public have an objective and clear understanding of the virus, so as not to miss the best period of treatment or suitable means due to ignorance. However, there are some messages out of balance in the process of information dissemination. Few things that mention other preventive measures for cervical cancer, such as with condoms in sex life and what symptoms of cervical cancer should be. In particular, there are only 32 pieces of information items that mentioned that the prevention of cervical cancer is not just a vaccination, which suggested that more necessary to do cervical cancer screening regularly. Especially, these messages mainly from the medical professionals and organizations who have right knowledges about the cervical cancer, showed more professional consideration. So mainly messages should make a reflection about why missed some important and key point. And readers should have a critical and logical 
thinking about these messages.

For the RQ3, the target audience was mainly women $(91.5 \%, \mathrm{~N}=109)$, whose age was between 16 and 26, which consistent with many studies and data showed that cervical cancer is the second most common female cancer in the world, and the HPV9 vaccine is much more urgent for women group. Especially, the HPV9 is more suitable for young ladies. The messages also discussed male's condition. There were 17 pieces of information discussing whether men should also be vaccinated. Among them, six items suggest that men also need to inject, resist the risk, and bravely go to Hong Kong and Australia for injection; and 11 information indicates that men are not suitable for injection. The reason is that the current domestic market for either bivalent or tetravalent HPV vaccines or nine-valent HPV vaccines has only been clinically tested for women, and there are no clinical trial data for men. Therefore, domestic males cannot be vaccinated.

For the last one, RQ4 proposed that the main publisher of HPV information in WeChat official accounts were nonmedical organizations $(72.27 \%, \mathrm{~N}=119), 19.33 \%$ messages are medical professionals and organizations. The LC4MP theory thinks the medium platform is the source of information, which decided message credibility to what extent can be trusted. What is more, recent source theory evidence suggests that the professional publisher has high level credibility, especially related the health problem. However, the most messages on WeChat platform were non-medical organizations, which can lead a low credibility to convey the message and may reduce the effectiveness of information dissemination. Why so many un-official platforms release information? One reason may be the social media of WeChat's self-media attribute. On social media platforms, everyone can create their own account and output information to win the favor of fandom.

According to the headline messages, researcher can figure out the attitudes of WeChat platform to HPV9, mainly showed neutral messages (52.9\%), positive messages $(31.1 \%)$, and negative messages (15.9\%), which suggested the most information have a neutral attitude for the HPV vaccine. More detail could see below in table 2.

\begin{tabular}{lcc}
\hline \multicolumn{1}{c}{ Variables } & Count & Proportion (\%) \\
\hline Headlines & & \\
$\quad$ Positive & 37 & 31.1 \\
Neutral & 63 & 52.9 \\
Negative & 19 & 15.9 \\
Publisher Platform & & \\
$\quad$ Nonmedical organizations & 86 & 72.27 \\
$\quad$ Nonmedical individuals & 10 & 8.4 \\
$\quad$ Medical professionals and & 23 & 19.33 \\
organizations & & \\
Goals of Message & & \\
$\quad$ Awareness & 113 & 94.95 \\
$\quad$ Behavior & 2 & 1.68 \\
$\quad$ Knowledge gain & 4 & 3.36 \\
Severity & 45 & 37.82 \\
Susceptibility & 43 & 36.13 \\
Benefits & 81 & 68.07 \\
Barriers & 57 & 47.9 \\
\hline
\end{tabular}

Table 2. Frequency of HPV9 in WeChat official accounts (source: author's analysis)

Jurnal The Messenger, Vol. 12, No. 1, January 2020, pp. 63-73 
For now, researcher know that the most information was published by non-medical organizations with mainly convey awareness messages, and they basic have a neutral attitude. To found out more about the main publisher platform's attitudes about the HPV information, we carried out a series of chi-square test with software R 3.5.1. Chi-square test for headlines and main publisher platform is significant, $\chi 2(4, \mathrm{~N}=119)=13.84, p$ $<.01, \mathrm{~V}^{*}=.0 .241$, according to Cohen, the correlation strength around 0.3 is 'low.' Then researcher did a series of post hoc comparisons, the $\mathrm{z}$ value after Bonferroni correction was -2.773 . The result showed that differences between headlines and main publisher platform, which means that nonmedical organizations were more inclined to use a neutral attitude.

Furthermore, chi-square test for severity and main publisher platform is significant, $\chi 2(2, \mathrm{~N}=119)=6.8926, \mathrm{p}<.01, \mathrm{~V}^{*}=.0 .241$, according to Cohen, the correlation strength around 0.3 is 'low.' Then researcher did a series of post hoc comparisons, the $\mathrm{z}$ value after Bonferroni correction was -2.638 . The result showed that there no differences between severity and main publisher platform, more detail please see table 3 . And other variables did not show statistically significant with publisher platform, so generally speaking we know that nonmedical organizations have a neutral attitude to the vaccine.

\begin{tabular}{llccc}
\hline \multicolumn{2}{c}{ Variables } & \multicolumn{3}{c}{ Main Publisher Platform } \\
& & Nonmedical & Nonmedical & Medical \\
Organizations & Individuals & $\begin{array}{c}\text { Professionals \& } \\
\text { Organizations }\end{array}$ \\
\hline \multirow{3}{*}{ Headlines } & Positive & $32(2.327)$ & $0(-2.219)$ & $5(-1.078)$ \\
& Neutral & $37\left(-3.499^{*}\right)$ & $9(2.453)$ & $17(2.243)$ \\
Severity & Negative & $17(1.827)$ & $1(-0.538)$ & $1(-1.693)$ \\
\hline
\end{tabular}

Note: Adjusted Residuals are in Brackets

*Adjusted residuals $>+$ or -3

Table 3. The Contingency Table of Main Publisher Platform

(source: author's analysis)

Researcher analyzed the content of the HPV message on WeChat reference the framework that LC4MP and HPB model. Researcher found that severity, susceptibility, benefits, and barriers all have appeared in WeChat. Generally consisted of the instanced content; however, which the benefits were the most mentioned points to the public, the second was barriers. Severity and susceptibility will make the public feel a certain degree of fear of HPV, while the benefits of vaccination will make the public feel that they have found the right solution and thus have a positive attitude towards the vaccine. To design a right and useful health message, the above points should be considered as soon as possible. Plus, the medium has a neutral attitude to the HPV9 vaccine; the public has less awareness of its side effects. In general, we can still see that the public is optimistic and favorable about the HPV9.

On the other hand, this may also be related to the subject of the WeChat official accounts. The level is not uniform; most of them are non-professionals, lacking professional pieces of knowledge about HPV. Studies have shown that there are still many ways to prevent cervical cancer, such as the routine cervical cancer screening program before the vaccine (Cuzick et al., 2006). However, that content is so limited. Researcher need to pay more attention to the professional medium, which would be more convincing to the public. 


\section{Conclusion}

In summary, this research conclusions can be seen that the Chinese public is optimistic about the vaccine and willing to vaccinate actively. Mainly based on the Chinese herd mentality, lacking an objective judge and calm thinking. After all, cervical cancer vaccines are scarce in China. Government departments are very strict with drug regulation. Once the Chinese government approves the vaccine, it is circulated in the market; it means that it is safe and reliable. Therefore, many WeChat content will directly start to publicize where the HPV9 vaccine to inject, which is the most substantial demand for public psychology, but not a full and objective representation of the entire situation of this vaccine. The sum that, how to design a compelling health communication message in china, it is crucial to understand the most critical needs of the public. But why is screening for cervical cancer not hot in China? Maybe the psychology of Chinese, including the pursuit of new, chasing heat. Because on April 28, 2018, the State Drug Administration just approved the sale of a nine-valent HPV vaccine for the prevention of cervical cancer in China.

However, there are some limits to this research. There are too many parts that require careful thinking and improvement for a logical study. First of all, in the selection of samples, limited to the ability of reptiles, resulted in the final selection of samples can only be a convenient method. Second, lacking data such as comments, reading, and forwarding (which can also be counted as dependent variables), and to see how effective it is to the public.

\section{Acknowledgements}

The author would like to thank the "International Communication Association (ICA) ASPIKOM Regional Conference 2019'--host that contribute the paper and get the chance to publish this manuscript, and also my friends who sincerely assist in the research to crawl the data, so that this research can be completed properly.

\section{References}

Bradley, M. M., \& Lang, P. J. (1994). Measuring emotion: the self-assessment manikin and the semantic differential. Journal of Behavior Therapy and Experimental Psychiatry, 25(1), 49-59.

Carcioppolo, N., Jensen, J. D., Wilson, S. R., Collins, W. B., Carrion, M., \& Linnemeier, G. (2013). Examining HPV threat-to-efficacy ratios in the Extended Parallel Process Model. Health Communication, 28(1), 20-28.

Carpenter, C. J. (2010). A meta-analysis of the effectiveness of health belief model variables in predicting behavior. Health Communication, 25(8), 661-669.

Cuzick, J., Clavel, C., Petry, K., Meijer, C. J. L. M., Hoyer, H., Ratnam, S., Szarewski, A., Birembaut, P., Kulasingam, S., \& Sasieni, P. (2006). Overview of the European and North American studies on HPV testing in primary cervical cancer screening. International Journal of Cancer, 119(5), 1095-1101.

Dewi, R., \& Anisa, R. (2018). The Influence of Posyandu Cadres Credibility on Community Participation in Health Program. Jurnal the Messenger, 10(1), 83-92.

Hong, H. (2011). An extension of the extended parallel process model (EPPM) in television health news: The influence of health consciousness on individual message processing and acceptance. Health Communication, 26(4), 343-353.

Janz, N. K., \& Becker, M. H. (1984). The health belief model: A decade later. Health 
Education Quarterly, 11(1), 1-47.

Lang, A. (2006). Using the limited capacity model of motivated mediated message processing to design effective cancer communication messages. Journal of Communication, 56, S57-S80.

Lee, M. J., \& Cho, J. (2017). Promoting HPV vaccination online: message design and media choice. Health Promotion Practice, 18(5), 645-653.

Li, S., Hu, T., Lv, W., Zhou, H., Li, X., Yang, R., Jia, Y., Huang, K., Chen, Z., Wang, S., Tang, F., Zhang, Q., Shen, J., Zhou, J., Xi, L., Deng, D., Wang, H., Wang, S., Xie, X., \& Ma, D. (2013). Changes in Prevalence and Clinical Characteristics of Cervical Cancer in the People's Republic of China: A Study of 10,012 Cases From a Nationwide Working Group. The Oncologist, 18(10), 1101-1107. https://doi.org/10.1634/theoncologist.2013-0123

Metcalfe, D., Price, C., \& Powell, J. (2011). Media coverage and public reaction to a celebrity cancer diagnosis. Journal of Public Health, 33(1), 80-85.

Mubarok, M. (2018). Communication Strategy Based on Islam Value of U-Jek Online Taxibike (Ojek) in Semarang. Jurnal The Messenger, 10(1), 24-33.

Nan, X., \& Daily, K. (2015). Biased assimilation and need for closure: Examining the effects of mixed blogs on vaccine-related beliefs. Journal of Health Communication, 20(4), 462-471.

Park, S.-Y. (2012). The effects of message framing and risk perceptions for HPV vaccine campaigns: focus on the role of regulatory fit. Health Marketing Quarterly, 29(4), 283-302.

Rogers, R. W. (1985). Attitude change and information integration in fear appeals. Psychological Reports, 56(1), 179-182.

Rosenstock, I. M. (2005). Why people use health services. The Milbank Quarterly, 83(4).

Shi, J., \& Salmon, C. T. (2018). Identifying opinion leaders to promote organ donation on social media: network study. Journal of Medical Internet Research, 20(1), e7.

Watson, M., Shaw, D., Molchanoff, L., \& McInnes, C. (2009). Challenges, lessons learned and results following the implementation of a human papilloma virus school vaccination program in South Australia. Australian and New Zealand Journal of Public Health, 33(4), 365-370.

Witte, K. (1992). Putting the fear back into fear appeals: The extended parallel process model. Communications Monographs, 59(4), 329-349.

Witte, K., \& Allen, M. (2000). A meta-analysis of fear appeals: Implications for effective public health campaigns. Health Education \& Behavior, 27(5), 591-615. 